Volume 11, Nomor 2, November 2019, pp 358-378 Copyright (C) 2017 Jurnal Akuntansi Maranatha, Program Studi Akuntansi, Fakultas Ekonomi, Universitas Kristen Maranatha. ISSN 2085-8698 | e-ISSN 2598-4977. http://journal.maranatha.edu

\title{
Perancangan Sistem Penjadwalan Dan Pengontrolan Produksi Perusahaan Padupadan
}

\author{
Marsheilla \\ Fakultas Ekonomi Program Studi Magister Manajemen - Universitas Katolik Parahyangan \\ (Jl. Merdeka No 30, Bandung) \\ katarinamarsheilla@gmail.com \\ Marsheilly \\ Fakultas Ekonomi Program Studi Magister Manajemen - Universitas Katolik Parahyangan \\ (J1. Merdeka No 30, Bandung) \\ marsheilly15@gmail.com
}

\begin{abstract}
The development of garment industry, especially for export, may bring certain challenges to Micro Small and Medium Enterprises (MSME). The company that export its products has to handle its production carefully, in particular for the export deadline. When the company fail to deliver its products on time, a high amount of fine, approximately $30 \%$ of total production cost, will be faced. Padupadan is a garment focusing on local product. To be competitive, it needs to improve its quality in both scheduling and production control. Orders has been accepted without actual information status of running order which cause delay and low product quality. Due to that situation, this company needs a system that assist decision making relating to controlling orders and performance of any parties in production process. Case study was used as method of this explanatory research. Data were analyzed using MIT 90's Framework and Data Flow Diagram. Design of Padupadan production system is related with 9 analyzed activities, namely marketing, sales order, production scheduling, human resource management, purchasing, receiving, warehouse (raw material), production, and warehouse (finished goods) which will be structured and standardized for the company. This system provides assistance in determining production scheduling target, system to control production that will help owner in evaluating employees, performance of production department and categorized supplier. Owner provides positive respon on the design since it can assist the company for future advance.
\end{abstract}

Keywords: Scheduling System Control; Production Control 


\section{Pendahuluan}

Industri garmen merupakan indusri yang membuat bahan baku menjadi barang jadi berupa pakaian, tas,topi, dll. Industri garmen membutuhkan bahan baku dari industri-industri lain seperti industri tekstil, industri pemintalan, industri benang, dll. Karena itu industri garmen memiliki peran yang sangat penting dalam perkembanganperkembangan industri tersebut di Indonesia. Khususnya peran industri garmen berpengaruh sangat besar pada industri tekstil, karena bahan pokok yang merupakan sumber utama industri garmen didapat dari industri tekstil (Ahira, 2005).

Pasar garmen domestik masih kurang disentuh, juga minat masyarakat terhadap produk garmen masih besar. Karena itu, jika produsen garmen IKM sulit untuk memasarkan produknya ke pasar internasional, mereka masih bisa memasarkannya ke dalam negeri. Dengan adanya perdagangan bebas, akses perdagangan China terbuka luas dan investor china dapat datang ke Indonesia. Hal ini menyebabkan lapangan kerja di Indonesia menjadi luas. Namun hal ini berdampak buruk bagi produk lokal, mereka kalah bersaing dengan produkproduk China dan pelaku usaha tersebut dapat dapat menjadi bangkrut dan beralih profesi menjadi pedagang. Hal ini akan berdampak terhadap tenaga kerja di Indonesia, mereka semakin kehilangan lapangan pekerjaan (Neraca, 2011).

Trend ekspor garmen pada gambar, juga memperlihatkan peluang pasar untuk Industri garmen di Indonesia, khususnya dalam bidang ekspor terus mengalami peningkatan dari tahun ke tahun khususnya dari tahun 2009 ke 2011; (dari US\$5 miliar hingga US\$ 8 miliar) pada tahun 2011.

Kedepannya, produk garmen akan ada yang kecenderungan impornya meningkat dan hal ini akan menjadi gangguan bagi Industri Kecil dan Menengah (IKM) di Indonesia. Pemerintah juga berharap agar produsen garmen IKM dapat membuat produk fashion untuk menghentikan serbuan produk impor. Salah satu cara untuk meningkatkan potensi IKM agar dapat hidup ditengah banyaknya produk-produk impor adalah dengan mendapatkan bantuan dari produsen garmen dari skala besar, misalnya dengan penambahan aksesori pada produk garmen di sektor industri besar dapat dilimpahkan ke IKM (Neraca, 2011).

Perusahaan Padupadan merupakan perusahaan yang termasuk dalam IKM, yaitu Usaha atau Industri Kecil. Perusahaan Padupadan yang memiliki 2 orang owner ini bergerak di bidang garmen, yaitu memproduksi pakaian berupa kaos dan juga menerima jasa makloon. Perusahaan Padupadan sudah dijalankan selama 5 tahun dan berlokasi di Jl. Pilar Kencana C8-79, Bandung. Perusahaan Padupadan memiiki 4 konsumen tetap khusus lokal yang berada di Bandung dan Jakarta.

Perusahaan Padupadan tidak memiliki banyak pegawai, hanya 9 orang dan owner sendiri suka turun tangan untuk membantu sekaligus merangkap sebagai mandor yang bertugas untuk mengawasi proses produksi yang berlangsung. Hampir semua industri garmen memiliki tingkat turnover pegawai yang tinggi. Pembagian kerja pada Perusahaan Padupadan pun masih belum jelas. Selain itu, Perusahaan Padupadan belum mempunyai penjadwalan dan pengontrolan produksi, sehingga terkadang order tidak selesai dengan tepat waktu sesuai dengan tanggal jatuh tempo.

Memang keterlambatan proses produksi ini tidak memberikan dampak yang signifikan, karena owner bisa negosiasi kepada konsumennya. Namun bila hal ini terus terjadi, order yang datang dapat berkurang, karena dimata konsumen Perusahaan Padupadan terkadang tidak tepat waktu dalam menyelesaikan ordernya.

Karena itu Perusahaan Padupadan membutuhkan suatu sistem yang dapat mengontrol penjadwalan dan pengontrolan produksi yang nantinya akan diterapkan agar mengurangi bahkan meniadakan 
keterlambatan proses produksi serta melihat hasil produksi tiap bagian dengan adanya pengontrolan, sehingga dapat dilihat bagian mana yang perlu dievaluasi dan ditingkatkan lagi kinerjanya. Perusahaan Padupadan belum secara maksimal memakai planning school-nya, yaitu ingin menekankan produknya pada kualitas, karena itu peneliti juga ingin mencoba memberikan saran dalam menjalankan planning school tersebut. Berdasarkan uraian latar belakang di atas, penelitian ini berjudul Perancangan Sistem Penjadwalan dan Pengontrolan Produksi Perusahaan Padupadan yang bernama Sistem Produksi Padupadan.

\section{Kerangka Teoritis}

\section{Sistem Informasi Manajemen (SIM)}

Teguh (1996) mengatakan Sistem Informasi Manajemen (SIM) merupakan suatu sistem berbasis komputer yang menyediakan informasi untuk pemakainya dengan kebutuhan serupa.

Kenneth C. Laudon dan Jane P. Laudon (2014) mengatakan aktivitas utama dalam Information System:

- Input (kegiatan mengumpulkan data)

- Process (membuat makna dari input)

- Output (memberikan informasi yang sudah diproses)

\section{Transaction Process System (TPS)}

Manajer operasional membutuhkan sistem yang mengarahkan aktivitas-aktivitas dan transaksi-transaksi dasar dari organisasi, seperti penjualan, faktur, dan kredit. TPS menyediakan informasi semacam yang dapat membantu manajer dalam mengarahkan aktivitas dan transaksi dasar di organisasi (C. Laundon \& P. Laoudon, 2014).

Fungsi utamanya adalah untuk menjawab pertanyaan-pertanyaan rutin untuk menelusuri arus transaksi organisasi. TPS dibutuhkan oleh para manajer dalam memonitor status internal operasi dan hubungan perusahaan dengan lingkungan 360 eksternal (C. Laundon \& P. Laoudon, 2014).

Tujuan utama dari TPS adalah untuk mengotomatisasi tangkapan dan rekaman dari sistem informasi mengenai transaksitransaksi yang terjadi saat pelatihan bisnis.TPS seperti mempunyai kemampuan untuk menggenerasi laporan-laporan yang memberikan variasi dari detail dalam atau kesimpulan dari peristiwa yang ditangkap oleh sistem. TPS adalah sandaran utama dari organisasi bisnis modern dan disubjekkan untuk mendesign ulang, banyak kesempatan-kesempatan baru terbuka untuk sistem analis (Marakas, 2011).

\section{Management Information System (MIS)}

MIS merupakan sistem berbasis komputer yang menyediakan berbagai informasi, dapat digunakan untuk kebutuhan yang serupa (Raymond McLeod, 2010).

MIS sering dikarakteristikan sebagai sebuah peningkatan dari TPS dengan anggapan bahwa itu diterima sebagai input data mentah dari TPS dan MPS mengubahnya menjadi laporan yang berarti atau grafik yang direncanakan untuk membantu para manager dalam perencanaan dan pengontrolan bisnis (Marakas, 2011).

Maka, MIS merupakan sistem berbasis komputer yang menyediakan berbagai informasi, sebagai sebuah peningkatan dari TPS yang merupakan input untuk MIS kemudian diubah menjadi sebuah laporan atau grafik yang dapat membantu para manager dalam perencanaan dan pegontrolan bisnis (Marakas, 2011).

Informasi menjelaskan suatu sistem yang terjadi pada masa lampau, saat ini dan masa depan. Informasinya berupa laporan periodik, laporan khusus dan keluaran dari hasil simulasi matematika. Output inilah yang akan digunakan para manajer dan non manajer untuk membuat keputusan dan menanggulangi masalah yang ada (Raymond McLeod, 2010). 
MIS sendiri merupakan sebagian dari sistem informasi yang digunakan oleh manajemen pada tingkat menengah dan informasi yang didapat dari TPS untuk masa depan dengan cara memonitor, mengontrol, dam memprediksi setiap kinerjanya.

\section{Pengawasan Produksi (Production Control)}

Semua kegiatan dalam suatu perusahaan pabrik harus diarahkan untuk menjamin kontinuitas dan koordinasi kegiatan juga untuk menyelesaikan produk dengan bentuk, kuantitas dan waktu yang diinginkan dalam batas biaya yang direncanakan. Pengawasan produksi bertugas untuk mengawasi aliran pekerjaan dalam suatu pabrik, sehingga ada kemajuan secara sistematis dari suatu bagian ke bagian yang lain tanpa ada kecacatan atau kelambatan dalam pengerjaan (Assauri, 2016).

Pengawasan produksi adalah kegiatan mengoordinasi aktivitas-aktivitas pengerjaan atau pengelolaan agar dapat selesai dengan waktu yang telah ditetapkan dengan efektif dan efisien. Pengawasan produksi merupakan suatu sistem jaringan syaraf dari suatu pabrik yang mengawasi jalannya proses produksi agar barangbarang yang dihasilkan sesuai dengan rencana yang dibuat, baik mengenai harga, biaya, kuantitas, maupun hasilnya (Assauri, 2016).

Keuntungan yang dapat diperoleh dengan adanya pengawasan produksi dalam suatu perusahaan:

1. Dapat membantu tercapainya operasi produksi yang efisien dari suatu perusahaan pabrik. Dalam pengerjaan suatu pesanan, pengawasan produksi menjamin tepatnya dan lebih positifnya penyelesaian pesanan dan waktu penyerahannya.

2. Membantu merencanakan prosedur pengerjaan yang kacau dan sembarangan, sehingga dapat lebih sederhana. Hal ini tidak hanya akan menambah efisiensi pabrik, tetapi juga membuat pekerjaan yang ada lebih mudah dikerjakan. Selain itu, umumnya para pekerja lebih suka untuk bekerja dengan hasil yang lebih baik, jika diawasi dan direncanakan, sehingga akan menaikkan moral pekerja.

3. Menjaga agar tersedia pekerjaan atau kerja yang dibutuhkan pada titik minimum, agar dapat dilakukan penghematan dalam penggunaan tenaga kerja dan bahan (Assauri, 2016).

Bagian pengawasan produksi dan memberinya tanggung jawab untuk mengetahui keadaan dari seluruh pesanan dalam pabrik dan mengoordinasikan seluruh aspek pengerjaannya dari pesanan diterima hingga siap untuk diserahkan kepada pelanggan. Pengawasan produksi merupakan fungsi staf yang memberikan petunjuk-petunjuk untuk berbagai bagian dari pabrik, menunjukkan apa yang harus mereka lakukan dan kapan harus melakukannya (Assauri, 2016).

\section{Management Control System (MCS)}

Menurut Horngren, Datar, Foster, Rajan, \& Ittne (2017), Management Control System adalah mengumpulkan dan menggunakan informasi untuk membantu dan mengoordinasikan keputusan perencanaan dan kontrol seluruh organisasi, serta untuk membimbing perilaku dari manajer dan karyawan lainnya. Management Control System yang berisikan mengenai informasi finansial dan non-finansial, dibagi dalam empat perspektif:

\section{Financial perspective}

Contohnya: harga saham, pendapatan, return on investment, cashflow dari operasi, dan cost per gallon of gasoline

2. Customer perspective

Contohnya: kepuasan konsumen, waktu yang diambil untuk merespon request dari konsumen untuk produk, pembelian ulang oleh konsumen, dan market share dalam segmentasi pasar 


\section{Internal-business-process perspective}

Contohnya: (dalam perusahaan bensin) pengiriman tepat waktu bensin dari kilang bensinnya ke stasiun retail, kualitas bensin, jumlah hari yang hilang karena kecelakaan dan masalah lingkungan, kecepatan servis di stasiun retail, keramahan pegawai, persediaan dari kenyamanan toko

4. Learning-and-growth perspective

Contohnya: kepuasan pegawai, kehadiran, kapabilitas sistem informasi, dan jumlah dari proses dengan real-time feedback

Design yang baik untuk Management Control System dalam sebuah perusahaan menggunakan kedua informasi dari perusahaan, yaitu pendapatan dan kepuasan pegawai serta dari luar perusahaan, yaitu harga saham dan kepuasan konsumen (Horngren, Datar, Foster, Rajan, \& Ittner, 2017).

\section{Formal and Informal System}

Management Control System terdiri dari sistem kontrol formal dan tidak formal. Management Control System yang formal dari sebuah perusahaan termasuk aturan yang jelas, prosedur, ukuran kinerja, dan rencana insentif yang membimbing perilaku dari manager dan pegawai yang lain. Sedangkan Management Control System yang informal termasuk nilai saham, loyalitas dan komitmen bersama antara perusahaan dan membernya, budaya perusahaan, dan norma yang tidak tertulis mengenai perilaku yang diterima untuk manager dan pegawai yang lainnya (Horngren, Datar, \& Rajan, 2012).

\section{Evaluating Management Control System}

Menurut Horngren, Datar, \& Rajan (2012) Agar Management Control System efektif harus berhubungan erat dengan strategi dan goal perusahaan dan harus didesign untuk dapat mendukung tanggung jawab organisasi dari individual manager. Management Control System juga harus memotivasi manager dan pegawainya.

\section{Motivasi}

Keinginan untuk mencapai tujuan yang diinginkan dikombinasikan dengan mengejar yang dihasilkan dari tujuan tersebut

2. Goal congruence

Muncul ketika individu dan group bekerja untuk mencapai tujuan organisasi, karena itu manager mengambil langkah sendiri bekerja dengan minatnya yang bekerja sama dengan seluruh tujuan dari top management.

\section{Effort}

Sejauh mana manager berusaha atau berusaha keras dalam rangka untuk meraih tujuan perusahaan. Usaha berjalan dalam aktivitas fisik, maupun aktivitas mental dan fisik.

Sebagai hasilnya, Management Control System memotivasi pegawai untuk mau berusaha dengan memberikan reward atau penghargaan untuk pencapaian dari tujuan yang terlihat, seperti pencapaian keuntungan. Penghargaan dapat berupa monetary (uang, membagi saham perusahaan, penggunaan mobil perusahaan, membership di suatu tempat) atau nonmonetary (gelar yang lebih baik, tanggung jawab lebih besar, otoritas atas jumlah pegawai yang lebih besar).

\section{Metode Penelitian}

Jenis penelitian yang digunakan yaitu berdasarkan tujuan dan berdasarkan proses. Berdasarkan tujuan digunakan metode eksploratori. Menurut Silalahi (2012) penelitian eksploratori merupakan penelitian yang bersifat menjelajah, betujuan untuk memperdalam pengetahuan mengenai suatu gejala tertentu, atau mendapatkan ide-ide baru mengenai gejala itu, dengan maksud untuk merumuskan masalahnya secara lebih terperinci atau untuk mengembangkan hipotesis. Dalam hal ini masalahnya sangat terbuka dan belum ada hipotesis. 
Sedangkan berdasarkan proses, menggunakan metode kualitatif yang menurut Silalahi (2012), metode kualitatif merupakan suatu strategi penelitian yang menekankan kata-kata daripada kuantifikasi dalam pengumpulan dan analisis data, menekankan pendekatan induktif untuk hubungan antara teori dan penelitian, yang tekanannya pada penempatan penciptaan teori (generate of theory). Oleh karena itu, penelitian kualitatif didefinisikan sebagai suatu proses penyelidikan untuk memahami masalah sosial berdasarkan pada penciptaan gambaran holistik lengkap yang dibentuk dengan kata-kata, melaporkan pandangan informan secara terperinci dan disusun dalam sebuah latar alamiah.

\section{Populasi Sampel}

Pemilihan samplenya digunakan teknik pemilihan sample secara kebetulan atau aksidental (convenience sampling). Menurut Silalahi (2012) pemilihan secara kebetulan atau aksidental merupakan pemilihan sampel dari siapa saja yang kebetulan dijumpai menurut keinginan peneliti. Pemilihan sampel akan mudah, baik dalam menggunakan waktu sebaikbaiknya maupun faktor biaya. Metode pemilihan sampel ini digunakan karena Perusahaan Padupadan tidak memiliki pencatatan apapun dalam perusahaannya, owner memberikan data terbarurnya, karena tidak ada pencatatan maupun penyimpanan data perusahaan apapun dalam periode yang lama.

Dalam penelitian ini, populasi yang digunakan adalah seluruh data yang berkaitan dengan kegiatan produksi Perusahaan Padupadan selama 1 bulan. Sedangkan sampel yang digunakan adalah sebagian data yang berkaitan dengan kegiatan produksi Perusahaan Padupadan selama 1 bulan. Karena hanya akan dirancangkan bagaimana tampilan sistem yang baik bagi Perusahaan Padupadan, maka data selama 1 bulan cukup, hanya dipakai untuk membuatkan contoh rancangan tampilan sistem.

\section{Teknik Analisis Data}

Analisis data dilakukan untuk menjawab pertanyaan-pertanyaan penelitian atau untuk menguji hipotesis penelitian yang telah dinyatakan sebelumnya. Analisis data adalah proses penyederhanaan data dan penyajian data dengan mengelompokkannya dalam suatu bentuk yang mudah dibaca dan diintepretasi (Silalahi, 2012).

Peneliti menggunakan MIT 90's Framework dan DFD (Data Flow Diagram) sebagai alat atau tools untuk menganalisis cara kerja atau alur kegiatan bisnis yang sedang berjalan pada Perusahaan Padupadan saat ini. Peneliti akan mencoba menggambarkan usulan DFD yang baru, maksudnya peneliti ingin membuat sistem baru yang dirasa lebih baik untuk dijalankan pada Perusahaan Padupadan yang dapat membuat Perusahaan Padupadan menjadi lebih baik dalam proses produksinya.

Sistem Informasi merupakan program yang menyediakan dasar untuk penangkapan dan penyebaran data di seluruh organisasi dengan dibantu oleh IT. Sebagai sistem informasi dan teknologi menjadi lebih kompleks, karena merupakan elemen penting untuk organisasi dalam mengatur dan mengontrol efektivitas perusahaan melalui standar kebijakan, privasi, dan perlindungan data (Levy \& Powel, 2005).

\section{Hasil Penelitian dan Pembahasan}

Pada bagian ini akan akan dibahas mengenai inti dari penelitian ini, yaitu bagaimana cara kerja Perusahaan Padupadan sekarang ini? Apakah proses produksi yang dilakukan oleh Perusahaan Padupadan sudah dilakukan secara maksimal dan baik? Bagaimana pencatatan semua sumber yang ada dalam Perusahaan Padupadan? Apa solusi yang sebaiknya diberikan agar Perusahaan Padupadan dapat lebih berkembang lagi dari sekarang dengan 
adanya teknologi informasi yang sedang berkembang sekarang ini? Bagaimanakah rancangan sistem yang diusulkan dapat bekerja pada Perusahaan Padupadan?

\section{MIT 90'S Framework}

Perusahaan Padupadan merupakan perusahaan berjenis IKM atau Industri Kecil dan Menengah yang bisa dibilang belum cukup lama berdiri, yaitu baru 5 tahun. Perusahaan Padupadan bergerak di bidang garmen, yang memproduksi kaos dan juga menerima jasa makloon. Saat ini usahanya cukup maju, namun dalam menjalankan usahanya owner belum menerapkan strategi apapun. Kedepannya owner berencana ingin menerapkan strategi planning school, yang mengutamakan pada kualitas produk. Strategi planning school merupakan strategi yang diambil untuk diterapkan dengan dianalisa dahulu. sekarang ini untuk meningkatkan kualitas produknya, Perusahaan Padupadan sudah mempunyai bagian quality control, namun bagian quality control pada Perusahaan Padupadan belum berfungsi secara maksimal dalam meningkatkan kualitas produknya. Karena itu, agar perusahaan lebih dapat maju dan berkembang lagi kedepannya, strategi planning school yang lebih mengutamakan pada kualitas produk yang dihasilkan ingin diterapkan pada Perusahaan Padupadan.

Sekarang ini banyak customer yang ingin mendesign sendiri pakaiannya dan lebih ingin yang kualitasnya bagus agar dapat dijual kembali, mungkin alasan ini salah satu alasan mengapa ada 4 customer tetap hingga saat ini. Teman juga cukup berperan penting, mereka membantu marketing Perusahaan Padupadan melalui Word of Mouth, sehingga karena semua itu Perusahaan Padupadan dapat bertahan hingga saat ini.

Perusahaan Padupadan dalam menjalankan usahanya ada 14 kegiatan secara keseluruhan. Proses pembuatan kaos dari awal hingga menjadi bahan jadi didukung oleh bagian-bagian yang ada dalam perusahaan. Perusahaan Padupadan memiliki 9 (sembilan) orang pegawai untuk bagian produksi dan 2 (dua) orang owner yang hampir menjalankan semua kegiatan dari Perusahaan Padupadan.

Owner di sini merangkap sebagai marketing, research and development, sales order, production scheduling, HRM, payroll, purchasing, receiving dari supplier, warehouse (raw materials dan finished goods), account payable, logistic (dengan menyuruh pegawai), dan account receiveable dan juga merangkap sebagai mandor yang mengawasi jalannya proes produksi. Untuk lebih mengerti seperti apa kegiatan yang terjadi dalam Perusahaan Padupadan, dapat dilihat pada gambar 1 .

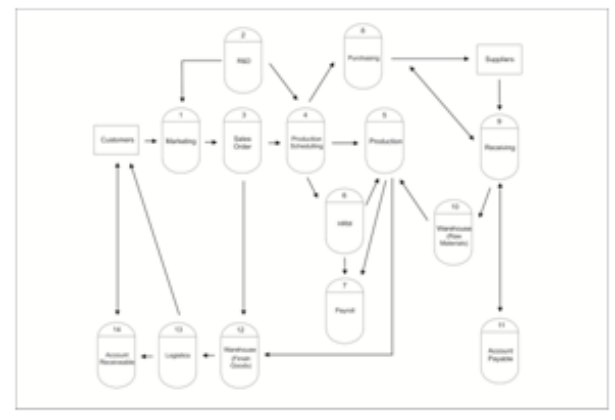

\section{Gambar 1 \\ Kegiatan Perusahaan Padupadan Sumber: Pengolahan data}

Pada tahap awal, owner melakukan proses marketing atau pemasaran. Pada proses marketing owner membuat design dan samplenya lalu menawarkannya kepada konsumen langganan dan konsumen lainnya hingga terjadi proses jual beli. Dari proses marketing ini, owner menerima kritikan dan request sehingga memberikan pengalaman untuk design-design yang akan dibuat owner kedepannya, dan ini merupakan proses reseach and development.

Saat order telah diterima, dilanjutkan pada proses sales order, yaitu owner akan mencatat detail pesanan untuk kemudian dilanjutkan ke proses production schedulling. Pada proses ini, detail pesanan yang telah didapat dari bagian sales order 
dilihat dan disiapkan kebutuhan akan pegawai dari HRM, dan bahan dari purchasing untuk kemudian dilanjutkan pada proses produksi untuk pengerjaan pesanan.

Proses HRM dilakukan untuk mencari dan merekut pegawai baru dan memaintain-nya. Penggajian dalam Perusahaan Padupadan dilakukan dengan memberikan upah secara bulanan untuk pegawai tetap dan upah borongan khusus untuk pegawai bagian sewing (sesuai dengan jumlah produk yang dikerjakan oleh masing-masing pegawai). Proses purchasing merupakan kegiatan memesan dan membeli bahan yang dibutuhkan dalam proses produksi. Dari sini akan dilanjutkan pada proses receiving, yaitu proses dimana bahan yang dipesan sudah sampai diantar dari pabriknya ke Perusahaan Padupadan, dicek apakah bahan tersebut sesuai dengan pesanan apa tidak. Bila sesuai bahan akan diterima. Proses warehouse untuk raw material, yaitu proses dimana bahan yang sudah dicek dan diterima dicatat dan dimasukan ke dalam gudang. Account Payable akan membayarkan bahan yang telah dipesan tersebut sesuai dengan jangka waktu yang diberikan oleh supplier, biasanya sekitar 1 bulan.

Setelah bahan dan HRM sudah ada, maka dapat dilakukan proses produksi. Proses produksi dilakukan oleh 9 (sembilan) orang pegawai dan owner yang merangkap sebagai mandor. Bagian cutting (2 orang) bertugas untuk mencetak dan menggunting kain sesuai dengan polanya. Bagian sewing (5 orang) bertugas untuk menjahit pola yang sudah disablon hingga menjadi kaos. Bagian packing juga merangkap sebagai quality control (2 orang) bertugas untuk mengecek hasil kualitas obras dari tempat lain dan hasil dari sewing, kaos yang sudah cukup baik kualitasnya lanjut di steam dan dipacking.

Bila proses produksi telah selesai dilakukan, maka kaos yang sudah selesai dipacking, untuk menunggu waktu pengiriman, order ditaruh dahulu di gudang dan ini terjadi pada proses warehouse untuk finished good. Saat barang siap di kirim, proses berlanjut pada proses logistic, owner dibantu oleh pegawai yang sedang tidak sibuk untuk mengeluarkan dan menghitung barang dari gudang sesuai dengan jumlah order yang kemudian siap untuk dikirim kepada konsumen. Setelah barang sampai, Account Payable akan menunggu pembayaran dari pembeli yang diberi waktu 1 bulan untuk pembayarannya.

Terkadang pengerjaan produksi juga terlambat dari waktu yang dijanjikan, jumlah pegawai di sini hanya sedikit. Dalam hal inilah menurut peneliti Perusahaan Padupadan membutuhkan suatu sistem informasi yang dapat menangani masalah keterlambatan produksi dan juga untuk meningkatkan kualitas produk yang dihasilkan, yaitu dengan membuat penjadwalan dan pengontrolan produksi agar pengiriman produk ke customer tidak terlambat dan kualitas yang dihasilkan baik, karena semua pencatatannya masih secara manual dan kadang tidak sinkron antara pencatatan dan kenyataannya. Hal ini dibutuhkan untuk membantu perusahaan Padupadan dalam menjalankan strategi planning school dan agar perusahaan Padupadan dapat menjadi lebih berkembang lagi.

Namun agar pekerjaan cepat selesai dengan tepat waktu, tidak mungkin Perusahaan Padupadan menambah karyawan lagi di tiap-tiap bagian, karena hal ini akan menaikkan cost atau biaya operasional pada perusahaan.

Teknologi dalam Perusahaan Padupadan ada dua, yaitu dalam hal produksi yaitu mesin-mesin yng digunakan dan Sistem Informasi. Dalam prosesnya, Perusahaan Padupadan menggunakan internet untuk mendapatkan inspirasi dan gambar-gambar untuk design kaosnya. Namun teknologi dalam hal IT belum dimanfaatkan secara maksimal, karena pencatatan dalam Perusahaan Padupadan masih secara manual. Hal inilah yang 
menyebabkan pencatatan (khususnya data gudang) tidak spesifik dengan aktualnya.

Mesin-mesin yang digunakan untuk produksi kaos hampir semuanya memakai merk Jack. Ada beberapa jenis mesin yang digunakan dalam proses produksi, yaitu:

a. Mesin potong kain, menurut Hanlim (2014) dan wawancara dengan owner Perusahaan Padupadan pada 15 September 2014, pengertian lengkap dari mesin potong kain yang digunakan oleh Perusahaan Padupadan adalah sebagai berikut:

1) Mesin potong dengan pisau lurus atau vertikal (straight cutter)

Mesin potong yang mempunyai mata pisau berbentuk satu plat baja lurus dan saat memotong, mata pisau tersebut akan bergerak naik turun (dua arah). Alat ini digunakan untuk memotong susunan kain yang cukup tinggi. Ketinggian kain disesuaikan dengan panjang pisau dan kapasitas mesin potongnya.

2) Mesin potong kain dengan pisau bundar

Mesin potong yang mempunyai mata pisau berbentuk piringan. Saat memotong, mata pisau bergerak memutar (ke depan). Ukuran diameter pisau potong sekitar 2.5-10 inci. Alat ini digunakan unuk memotong kain dengan tumpukan yang tidak tinggi, karena terbatas dengan ukuran diameter pisau potong. Maksimum tumpukan tinggi kain adalah setengah dari diameter pisau yang dipakai.

b. Mesin jahit: mesin yang digunakan untuk menjahit bahan kaos.

c. Mesin roll atau potong : mesin yang digunakan untuk menghasilkan jahitan rantai dua baris. Jahitan dua rantai ini merapikan bagian bahu atas yang menghubungkan kerah dengan lengan kaos.

d. Mesin obras: mesin obras kaos ini hasilnya mirip dengan jahitan mesin obras biasa. Hanya fungsinya berbeda, pada mesin obras kaos untuk merapikan jahitan, juga digunakan untuk menjahit, terutama pada lipatan kain. Berbeda dengan mesin obras biasa yang hanya berfungsi untuk merapikan jahitan dengan cara memotong tepi pakaian.

e. Mesin overdeck: mesin yang digunakan untuk klim pada tepi atau ujung kaos, biasanya terdapat pada ujung tangan dan bagian bawah kaos. Selain itu dapat juga digunakan untuk menjahit kerah kaos bagian dalam sehingga terlihat rapi menutupi jahitan dan membuat jahitan tersebut akan terlindungi, awet dan tidak mudah lepas.

Bila dilihat dari teknologi di luar, kebanyakan garmen memakai mesin jahit yang memiliki merk Juki (dari Jepang), karena Juki terkenal ahli dalam mengembangkan mesin jahit selama bertahun-tahun (sudah lebih modern). Menurut Tnoton (2012), mesin jahit merk Juki dikenal sebagai mesin jahit terbaik, tidak hanya di Jepang namun juga di seluruh dunia. Produk Juki telah mendominasi pasar selama kurang lebih 65 tahun. Mesin jahit Juki merupakan produk terbaik dengan kualitas yang baik pula, karena hasil jahitannya sangat baik bila dibandingkan dengan mesin jahit lainnya.

Juga di zaman yang sudah modern ini, hampir semua perusahaan mengembangkan teknologinya, hal ini karena dengan adanya teknologi, semua hal menjadi praktis dan terkontrol. Begitu pula di beberapa garmen besar semua sudah menggunakan teknologi, namun bagi garmen yang masih kecil atau termasuk ke dalam IKM baru sedikit yang menggunakan teknologi. Begitu pula Perusahaan Padupadan, pemanfaatan teknologi dirasa belum maksimal, karena pencatatannya masih secara manual. Karena itu akan dicoba untuk merancangkan sistem berbasis komputer untuk Perusahaan Padupadan ke depannya.

Jadi dari kesimpulan diatas, akan dirancangkan sebuah ide baru untuk Perusahaan Padupadan yang ingin 
menerapkan strategi planning school dengan mengutamakan kualitas produk. Untuk menerapkan strategi planning school, perlu dirubah manajemen proses, dibantu dengan peran individual and roles untuk menerapkan strategi tersebut dan didukung dengan teknologi yang ada. Namun dalam prosesnya, akan lebih dilihat pada manajemen proses.

Dalam karya ilmiah ini, akan dibahas dan difokuskan pada 9 (sembilan) proses yang ada pada Perusahaan Padupadan pada gambar dan merupakan fokus dari MIT 90's Framework yang sebelumnya telah dibahas, yaitu pada bagian marketing, sales order, production schedulling, Human Resource and Management, purchasing, receiving, warehouse untuk raw material dan finished good dan production. Dan pada gambar akan dapat dilihat proses bisnis secara keseluruhan yang akan dibahas.

\section{Proses Bisnis Perusahaan Padupadan dan Rancangan yang Diusulkan}

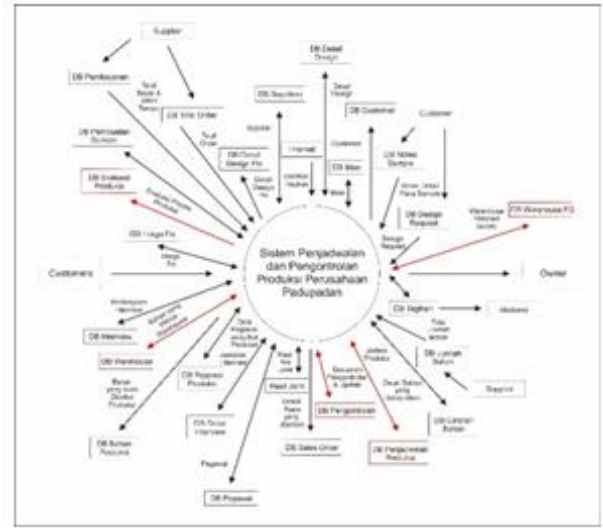

\section{Gambar 2}

\section{DFD Level 0 Perusahaan Padupadan Sumber: Pengolahan data}

Pada gambar 2 di atas, merupakan proses bisnis yang akan dibahas. Customer akan memberikan order kepada owner. Kemudian dirancangkan sistem penjadwalan dan pengontrolan produksi untuk pengerjaan proses order tersebut dengan melihat data-data yang masuk pada gambar diatas, sehingga pesanan tersebut sampai kepada konsumen dengan tepat waktu dan kualitas yang baik.

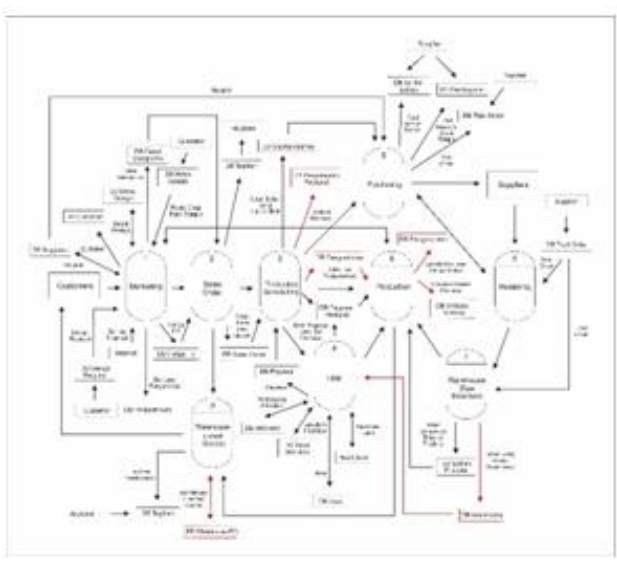

Gambar 3

\section{DFD Level 1 Perusahaan Padupadan (yang akan dibahas) Sumber: Pengolahan data}

Dari 9 proses yang akan dibahas dan keinginan owner untuk melakukan strategi planning school yang menekankan pada kualitas produk yang dihasilkan, dicoba untuk memberikan masukan atau usul kepada owner mengenai proses kerja yang terjadi didalamnya.

\section{1) Marketing}

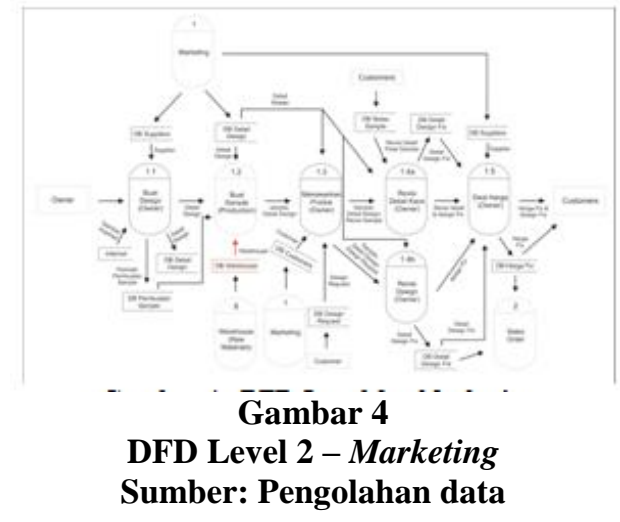


Dapat dilihat pada gambar 4 diatas, merupakan kegiatan marketing yang terjadi pada Perusahaan Padupadan. Owner membuat design kaos dengan mencari gambar dan inspirasi dari internet, juga dengan melihat data supplier untuk mengetahui bahan apa yang akan dipakai nantinya, yang nantinya akan menghasilkan data base detail design. Detail design nantinya akan diberikan kepada bagian produksi untuk dibuat sample kaos menggunakan bahan yang ada dari warehouse. Setelah sample jadi, owner menawarkan produk dengan membawa sample dan detail design kepada customer. Disini ada tiga hal yang akan dilakukan customer, pertama customer setuju akan design-nya, maka ia akan memberikan revisi kecil pada samplenya. Kedua, bila customer tidak setuju pada design-nya, ia akan memberikan design request yang nantinya akan owner lihat, apakah designnya bisa dibuat atau tidak. Bila design request yang diberikan customer tidak bisa dibuat, maka owner akan memberikan alternatif design pada customer. Bila customer sudah setuju dengan design-nya, maka akan lanjut pada proses deal harga. Bila harga yang diajukan disepakati oleh customer maka order yang diterima akan masuk ke dalam proses yang kedua, yaitu sales order.

\section{2) Sales Order}

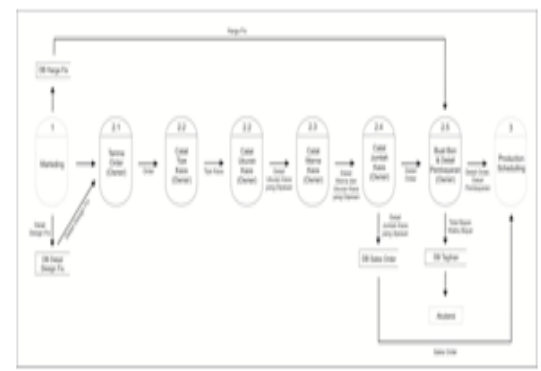

Gambar 5

DFD Level 2 - Sales Order

Sumber: Pengolahan data
Order dan detail design fix telah diterima oleh owner dari proses marketing, maka akan lanjut ke proses sales order pada gambar 5. Owner menerima order dari bagian marketing. Lalu mencatat tipe kaos yang dipesan, ukuran kaos, warna kaos dan jumlah kaos dari masing-masing warna dan ukurannya sehingga dihasilkan database sales order. Setelah semua total jumlah pesanan dicatat, owner membuat bon dan detail pembayaran dari data base harga fix yang dihasilkan dari proses sebelumnya menjadi database tagihan yang akan diurus oleh bagian akuntansi (owner sendiri). Biasanya waktu pembayaran akan diberi waktu selama 1 bulan oleh Perusahaan Padupadan untuk melunasi pembayarannya dari barang diterima nantinya. Kemudian akan dilanjutkan pada proses production schedulling untuk memulai penjadwalan produksi.

Sebelum menerima order, bagian sales order akan melihat dahulu sampai dimana proses order yang sedang dikerjakan sekarang, baru dari situ, dapat diputuskan apakah order akan diterima ataukah tidak. Atau owner dapat bernegosiasi dengan customer-nya untuk mengubah tanggal deadline (mungkin akan diundur), dengan melihat dari data sales order dan penjadwalan produksi produk yang sedang dikerjakan.

\section{Tabel 1}

Tampilan dari Usulan Sistem Penentuan Penerimaan Order

\begin{tabular}{|l|l|l|l|l|l|}
\hline No & $\begin{array}{l}\text { Order yang } \\
\text { Dikerjakan }\end{array}$ & $\begin{array}{l}\text { Proses } \\
\text { Cutting } \\
\text { (target) }\end{array}$ & $\begin{array}{l}\text { Proses } \\
\text { Sablon } \\
\text { (target) }\end{array}$ & $\begin{array}{l}\text { Proses } \\
\text { Sewing } \\
\text { (target) }\end{array}$ & $\begin{array}{l}\text { Proses } \\
\text { Packing } \\
\text { (target) }\end{array}$ \\
\hline $\mathbf{1}$ & $\begin{array}{l}\text { Client } \\
\text { XYZ }\end{array}$ & $\begin{array}{l}16-11- \\
14\end{array}$ & $\begin{array}{l}18-11- \\
14\end{array}$ & $\begin{array}{l}21-11- \\
14\end{array}$ & $\begin{array}{l}25-11- \\
14\end{array}$ \\
\hline $\mathbf{2}$ & $\begin{array}{l}\text { Client : } \\
\text { ABC }\end{array}$ & $19-11-$ & $21-11-$ & $24-11-$ & $27-11-$ \\
14 & 14 & 14 & 14 \\
\hline $\mathbf{3}$ & $\begin{array}{l}\text { Client : } \\
\text { Corry (524 } \\
\text { kaos) }\end{array}$ & $4-12-14$ & $6-12-14$ & $10-12-$ & $14-12-$ \\
& & & 14 & 14 \\
\hline $\mathbf{4}$ & & & & & \\
\hline $\mathbf{5}$ & \multicolumn{2}{|l}{} & & \\
\hline
\end{tabular}


Owner dapat melihat kapan target produksi yang sedang dijalankan. Dari data tersebut, dalam pengambilan order yang akan datang owner akan dapat mengetahui bahwa saat ini order sudah pada proses mana, jadi bila order sudah pada proses sablon, atau sewing;owner dapat menerima order yang baru sembari menunggu datangnya barang yang dipesan dengan mengacu pada data supplier bahan (berapa lama masa keterlambatannya).

\section{3) Production Schedulling}

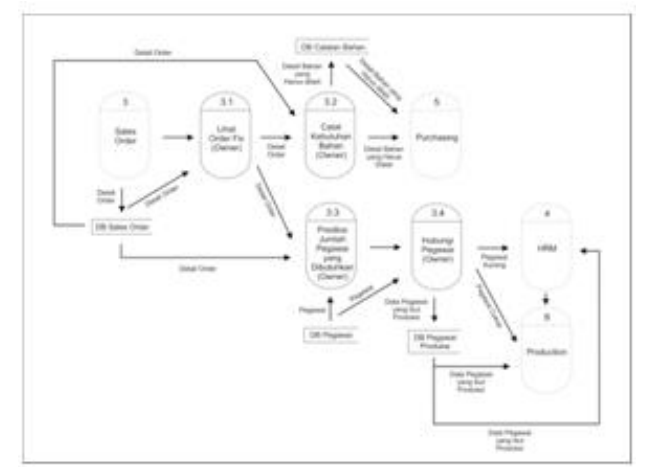

\section{Gambar 6 \\ DFD Level 2 - Production Schedulling (Existing) \\ Sumber: Pengolahan data}

Dari sales order, proses akan berlanjut ke production schedulling pada gambar 6 . Owner akan melihat order fix dari konsumen dari data sales order. Setelah itu owner akan mencatat kebutuhan bahan untuk produksi pesanan, untuk kemudian dilajutkan ke bagian purchasing untuk membeli bahan yang dibutuhkan. Lalu dari data sales order juga, owner akan memprediksi berapa jumlah pegawai yang dibutuhkan untuk produksi dengan melihat deadline order. Bila sudah diketahui berapa pegawai yang dibutuhkan (khususnya pegawai bagian jahit, karena bukan pegawai tetap), owner akan menghubungi pegawai untuk bagian sewing untuk konfirmasi lagi, apakah mereka dapat bekerja atau tidak. Bila pegawai bagian sewing dirasa sudah cukup, maka owner akan langsung lanjut ke bagian produksi, sambil menunggu bahan yang datang. Namun bila pegawai tidak cukup, akan berlanjut ke HRM atau proses perekrutan untuk mencari pegawai bagian sewing.

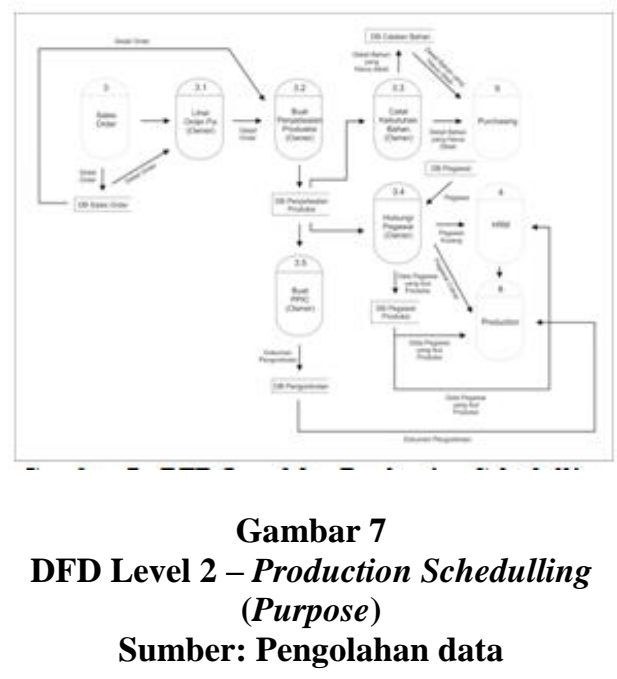

Gambar 7 akan dibahas mengenai production schedulling yang diusulkan. Owner akan melihat order fix dari konsumen dari data sales order. Setelah itu owner akan membuat penjadwalan produksi, dan mencoba membuat dokumen penjadwalan produksi, sehingga jalannya produksi lebih teratur karena sudah ada target pencapaian. Dari dokumen tersebut, owner akan mencatat kebutuhan bahan untuk produksi pesanan, untuk kemudian dilajutkan ke bagian purchasing untuk membeli bahan yang dibutuhkan. Selain itu, owner akan mendapatkan keterangan mengenai berapa jumlah pegawai yang dibutuhkan untuk produksi yang sudah diprediksi sebelumnya. Bila sudah diketahui berapa pegawai yang dibutuhkan (khususnya pegawai bagian jahit, karena bukan pegawai tetap), owner akan menghubungi pegawai untuk bagian sewing untuk konfirmasi lagi, apakah mereka dapat bekerja atau tidak. Bila pegawai bagian sewing dirasa sudah cukup, maka owner akan langsung lanjut ke bagian produksi, 
sambil menunggu bahan yang datang. Namun bila pegawai tidak cukup, akan berlanjut ke HRM atau proses perekrutan untuk mencari pegawai bagian sewing. Dari penjawalan produksi tersebut, owner akan membuat pengontrolan atau perintah pengerjaan yang akan digunakan sebagai acuan kapan pekerjaan harus mulai dan harus selesai juga untuk melihat kesalahan yang terjadi, yaitu pada bagian mana., pengontrolan tersebut akan diberikan kepada seseorang pegawai tetap untuk melihat, mengawasi, dan mencatat jalannya proses produksi. Dari lembaran tersebut, dapat diberikan evaluasi kinerja dari pihak yang terkait dengan proses produksi dan dapat dilihat darimana keterlambatan produksi berasal dan apa kira-kira penyebab dari keterlambatan tersebut.

Selain itu, ia juga bertugas untuk menghitung berapa banyak hasil pakaian yang dihasilkan oleh bagian sewing setiap pegawai, untuk kemudian data tersebut akan diolah ke bagian penggajian (karena upah yang diberikan untuk pegawai sewing bersifat borongan atau dibayar sesuai dengan jumlah yang diproduksi). Dengan adanya penjadwalan dan pengontrolan produksi, order akan dapat selesai dengan adanya target penjadwalan tiap bagian dan kesalahan dalam membuat produk dapat kita evaluasi dan mencari darimana sumber kesalahan tersebut, sehingga hasil kaospun akan semakin baik dari segi kualitas dan tingkat kesalahan lebih sedikit dari biasanya untuk order berikutnya.

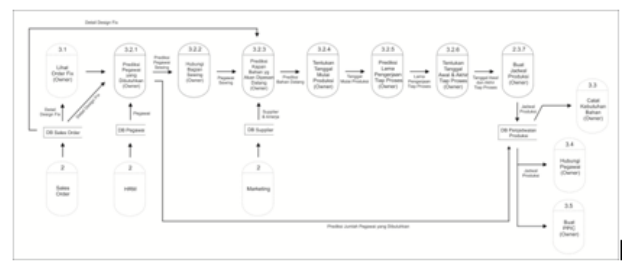

Gambar 8

DFD Level 3 - Buat Jadwal Produksi Sumber: Pengolahan data
Dalam membuat jadwal produksi, akan dibutuhkan beberapa proses didalamnya, dan dapat dilihat pada gambar 8 di atas. Dari data sales order, owner akan memprediksi, berapa jumlah pegawai yang dibutuhkan (khususnya bagian sewing, karena bukan pegawai tetap), lalu owner akan menghubungi pegawai bagian sewing untuk memastikan apakah pegawai memprediksi dengan jumlah pesanan dan model kaos yang dipesan, berapa banyak kebutuhan bahan dan kapan bahan akan sampai di perusahaan. Setelah itu, owner akan menentukan tanggal mulai produksi dan lama pengerjaan tiap prosesnya sehingga dapat ditentukan tanggal mulai dan berakhirnya tiap proses produksi, barulah dari keterangan tersebut dapat dibuat penjadwalan produksi. Penjadwalan produksi ini dibuat sebagai target pencapaian dari produksi dengan melihat sales order, sehingga kemungkinan tiap proses akan mengalami keterlambatan akan kecil (karena sudah ditargetkan). Dari penjadwalan produksi tersebut owner dapat mencatat kebutuhan bahan, menghubungi pegawai untuk produksi dan membuat dokumen pengontrolan proses produksi.

Tabel 2

\section{Tampilan dari Usulan Sistem Penjadwalan Produksi}

$\begin{array}{ll}\text { Client } & : \text { Corry (510) } \\ \text { Tanggal Order } & : \text { 3 Desember 2014 } \\ \text { Deadline } & : \text { 16 Desember 2014 }\end{array}$

\begin{tabular}{|c|c|c|c|c|c|c|}
\hline \multirow[t]{2}{*}{ No. } & \multirow{2}{*}{$\begin{array}{l}\text { Proses } \\
\text { Produlssi }\end{array}$} & \multicolumn{2}{|c|}{ Tanggal Mulai } & \multicolumn{2}{|c|}{ Tanggal Selesai } & \multirow{2}{*}{$\begin{array}{c}\text { Jumlah } \\
\text { yang } \\
\text { Dikerjalcan }\end{array}$} \\
\hline & & Target & Altual & Target & Altual & \\
\hline 1 & $\begin{array}{l}\text { Buat Pola } \\
\text { +Cutting }\end{array}$ & $\begin{array}{l}4-12- \\
14\end{array}$ & $\begin{array}{l}4-12- \\
14\end{array}$ & $\begin{array}{l}5-12- \\
14\end{array}$ & $\begin{array}{l}5-12- \\
14\end{array}$ & $510 \Rightarrow 524$ \\
\hline 2 & $\begin{array}{l}\text { Sablon + } \\
\text { QC Sablon }\end{array}$ & $\begin{array}{l}6-12- \\
14\end{array}$ & $\begin{array}{l}6-12- \\
14\end{array}$ & $\begin{array}{l}9-12- \\
14\end{array}$ & $\begin{array}{l}10-12- \\
14\end{array}$ & $510 \Rightarrow 524$ \\
\hline 3 & $\begin{array}{l}\text { Sewing + } \\
\text { QC } \\
\text { Sewing }\end{array}$ & $\begin{array}{l}10-12- \\
14\end{array}$ & $\begin{array}{l}11-12- \\
14\end{array}$ & $\begin{array}{l}13-12- \\
14\end{array}$ & $\begin{array}{l}14-12- \\
14\end{array}$ & $510 \Rightarrow 524$ \\
\hline 4 & $\begin{array}{l}\text { Steam } \\
\text { Packing }\end{array}$ & $\begin{array}{l}14-12- \\
14\end{array}$ & $\begin{array}{l}15-12- \\
14\end{array}$ & $\begin{array}{l}15-12- \\
14\end{array}$ & $\begin{array}{l}15-12- \\
14\end{array}$ & $510 \Rightarrow 524$ \\
\hline 5 & Pengiriman & $\begin{array}{l}15-12- \\
14\end{array}$ & $\begin{array}{l}15-12- \\
14\end{array}$ & $\begin{array}{l}16-12- \\
14\end{array}$ & $\begin{array}{l}16-12- \\
14\end{array}$ & $510 \Rightarrow 524$ \\
\hline
\end{tabular}


Pada tabel penjadwalan diatas, jumlah produksi dilebihkan untuk berjagajaga apabila ada gagal sablon. Selain itu, produksi dilebihkan sesuai dengan jumlah kain yang dipesan, sehingga kain tidak banyak tersisa dan masuk ke inventory. Owner akan bernegosiasi dengan konsumennya untuk produksi lebih banyak sesuai dengan jumlah kain yang dipesan. Tulisan yang diwarnai kuning menandakan bahwa proses pengerjaan tidak selesai dengan yang ditargetkan.

\section{4) HRM}

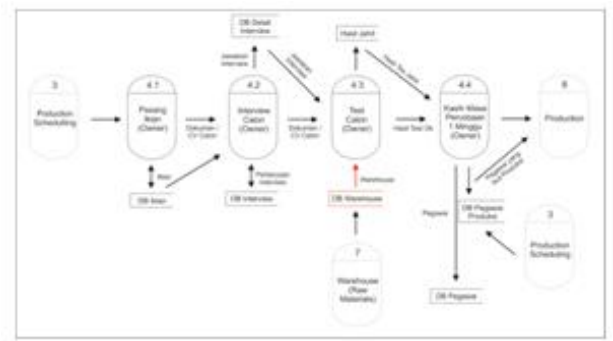

Gambar 9

\section{DFD Level 2 - HRM (Human Resource} Management)

Sumber: Pengolahan data

Bila jumlah pegawai kurang, dari production schedulling akan masuk ke proses HRM yang berisikan mengenai proses perekrutan pegawai pada gambar. Owner akan membuat dan memasang iklan di depan perusahaan atau media masa melalui data iklan yang telah dibuatnya. Bila pelamar atau calon pegawai datang, pegawai biasanya menyerahkan $\mathrm{CV}$ atau dokumen yang kemudian akan dibaca dan langsung di interview. Untuk interview owner akan menyiapkan pertanyaannya pada database interview yang akan dipakai nantinya. Setelah interview selesai, owner akan melanjutkan ke proses tes, yaitu owner akan memberikan bahan sisa dengan melihat database warehouse dan calon akan di tes jahit baju. Bila hasil tes bagus, maka pegawai akan diberi masa percobaan 1 minggu untuk bekerja di Perusahaan Padupadan.

\section{5) Purchasing}

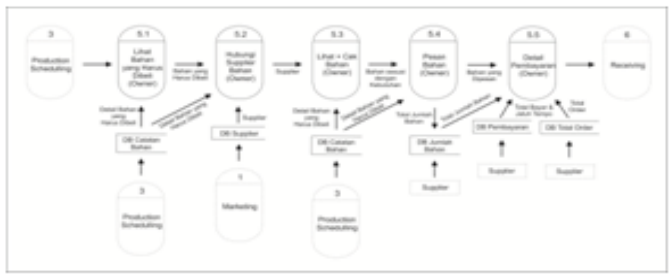

Gambar 10

DFD Level 2 - Purchasing

Sumber: Pengolahan data

Owner akan membeli bahan untuk produksi untuk mengerjakan pesanan konsumennya pada proses purchasing di gambar. Owner akan melihat bahan apa yang harus dibeli lalu menghubungi supplier untuk menanyakan apakah bahan yang dibutuhkan ada atau tidak pada supplier. Bila bahan ada, owner akan melihat dan mengecek bahan apakah sesuai atau tidak dengan yang diinginkan konsumen. Bila bahan sesuai, owner akan memesan bahan tersebut sesuai dengan kebutuhan dan mendapatkan detail pembayaran.

\section{6) Receiving}

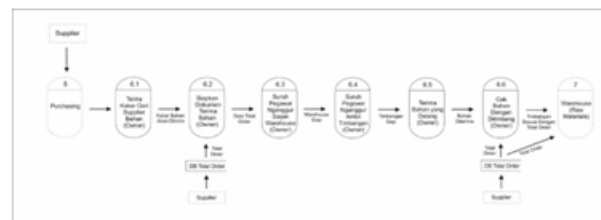

Gambar 11

DFD Level 2 - Receiving

Sumber : Pengolahan data

Setelah memesan bahan baku untuk membuat pesanan konsumen, owner akan menunggu bahan yang dipesan pada supplier datang. Pada proses receiving yaitu pada gambar, owner akan menerima kabar dari supplier, bahwa bahan akan dikirim pada hari tertentu. Sebelum bahan sampai, owner terlebih dahulu menyiapkan dokumen atau tanda terima bahan dengan 
melihat database total order untuk melihat berapa jumlah bahan yang dipesan. Kemudian owner akan menyuruh pegawai yang menganggur untuk menyiapkan atau merapikan warehouse untuk menaruh bahan yang akan datang dan menyuruh pegawai tersebut untuk mengambil timbangan (yang akan digunakan untuk mengecek total order). Saat bahan datang, owner akan menerima bahan tersebut dan akan dicek dengan ditimbang apakah jumlah bahan yang datang sesuai dengan pesanan ataukah tidak dengan melihat data base total order.Proses kemudian akan berlanjut ke proses warehouse untuk bagian raw materials.

\section{7) Warehouse (Raw Materials)}

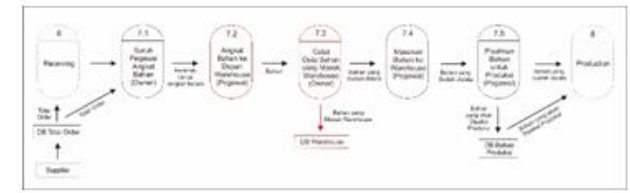

\section{Gambar 12 \\ DFD Level 2 - Warehouse (raw materials) Sumber : Pengolahan data}

Setelah menerima bahan yang dipesan untuk proses produksi dan diakurkan dengan data base total order, owner menyuruh pegawai yang sedang menganggur untuk membantunya mengangkat bahan untuk ditaruh di gudang, yang kemudian akan dipakai untuk proses produksi.

Owner sekarang tidak melakukan pencatatan dalam gudangnya, baik saat barang masuk maupun barang keluar untuk dipakai. Management inventory sangat dibutuhkan agar owner dapat mengetahui berapa banyak bahan yang masuk gudang dan yang keluar dari gudang. Hal ini juga dilakukan untuk mencegah beberapa faktor yang dapat terjadi pada perusahaan, seperti kecurangan (misalnya diambil oleh pegawai). Karena itu disusulkan agar saat barang sudah diterima dan dicek dari proses sebelumnya, yaitu proses receiving kemudian owner akan menyuruh pegawai yang menganggur untuk membantunya mengangkat bahan ke depan gudang, ditaruh dahulu barangnya di depan gudang, lalu catat data bahan yang masuk ke warehouse, sehingga akan didapatkan data base warehouse untuk raw material. Baru setelah data bahan yang masuk dicatat, pegawai dapat memasukan bahannya ke dalam gudang, yang kemudian akan dipakai untuk produksi.

Tabel 3

\section{Tampilan Usulan Sistem Warehouse Inventory List (Raw Materials)}

Total Inventory Value : $1.5 \mathrm{~kg}$

Inventory Items : Kain/ Bahan untuk produksi

\begin{tabular}{|l|l|l|l|l|l|l|}
\hline $\begin{array}{c}\text { Jenis } \\
\text { Bahan }\end{array}$ & $\begin{array}{l}\text { Warua } \\
\text { Bahan }\end{array}$ & $\begin{array}{l}\text { Bahan } \\
\text { Masul }\end{array}$ & $\begin{array}{l}\text { Jumlah } \\
\text { Bahan } \\
\text { Masul }\end{array}$ & $\begin{array}{l}\text { Baban } \\
\text { Keluar }\end{array}$ & $\begin{array}{l}\text { Jumlah } \\
\text { Bahan } \\
\text { Keluar }\end{array}$ & $\begin{array}{c}\text { Sisa } \\
\text { Bahan }\end{array}$ \\
\hline Katun & Pink & $\begin{array}{l}2-11- \\
14\end{array}$ & $18 \mathrm{~kg}$ & $\begin{array}{l}2-11- \\
14\end{array}$ & $\begin{array}{l}16.5 \mathrm{~kg} \\
1 \mathrm{~kg}\end{array}$ \\
\hline Spandex & $\begin{array}{l}\text { Biru } \\
\text { Muda }\end{array}$ & $\begin{array}{l}15-11- \\
14\end{array}$ & $24 \mathrm{~kg}$ & $\begin{array}{l}17-11- \\
14\end{array}$ & $22 \mathrm{~kg}$ & $0.5 \mathrm{~kg}$ \\
\hline Katun & Putih & $\begin{array}{l}3-12- \\
14\end{array}$ & $25 \mathrm{~kg}$ & $\begin{array}{l}3-12- \\
14\end{array}$ & $24 \mathrm{~kg}$ & \\
\hline & & & & & & \\
\hline & & & & & & \\
\hline & & & & & & \\
\hline & & & & & & \\
\hline
\end{tabular}

\section{8) Production}

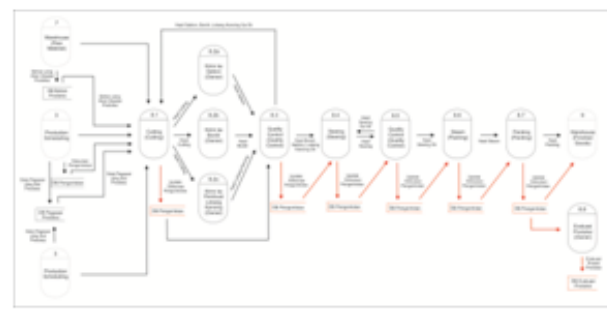

Gambar 13

DFD Level 2 - Production

Sumber: Pengolahan data

Gambar 13 diatas berisi mengenai proses produksi pada Perusahaan Padupadan. Dari awal, yaitu cutting dilakukan oleh bagian cutting, termasuk didalamnya membuat pola. Setelah itu melihat dari order, apakah menggunakan sablon, bordir, pembuatan 
lubang kancing atau bahkan ketiganya, maka baju akan dikirim ke masing-masing supplier. Bila sudah selesai, akan dilakukan quality control (QC) oleh bagian quality control. Bila hasil sablon, bordir, dan pembuatan lubang kancing kurang baik, maka proses akan kembali ke bagian cutting untuk membuat ulang lagi sejumlah order yang kurang baik. Sedangkan bila hasil dari sablon, bordir, pembuatan lubang kancing baik maka proses akan berlanjut ke proses sewing oleh bagian sewing, lalu dicek lagi hasilnya oleh bagian quality control (QC). Bila hasil jahitan kurang baik, maka proses akan kembali lagi ke bagian sewing untuk diperbaiki, sedangkan bila hasil jahitan baik proses akan berlanjut ke proses steam lalu order siap di-packing. Kemudian berlanjut pada proses warehouse finished good untuk menunggu proses pengiriman pesanan.

Dengan adanya dokumen pengontrolan, owner dapat mengecek dimana terjadinya keterlambatan kesalahan (bila ada), sehingga dapat lebih diperbaiki lagi pada bagian tersebut. maka dari itu diusulkan satu proses tambahan yaitu evaluasi produksi. Dari dokumen pengontrolan yang dibuat akan didapatkan evaluasi dari satu kegiatan produksi dalam pembuatan pesanan dan dapat dievaluasi atau diperbaiki lagi kedepannya, sehingga Perusahaan Padupadan menjadi perusahaan yang lebih baik lagi ke depannya. Maka, otomatis kualitas dari barang yang diproduksi akan lebih baik lagi dan juga dengan penjadwalan produksi yang diusulkan diatas, proses produksi pada Perusahaan akan menjadi lebih baik.

\section{9) Warehouse (Finished Goods)}

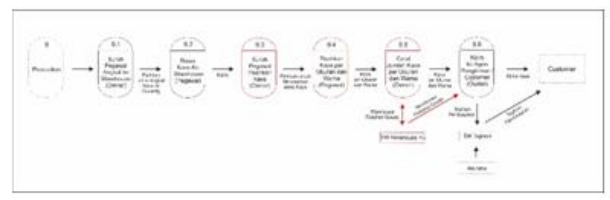

\section{Gambar 14}

\section{DFD Level 2 - Warehouse (Finished Goods)}

Sumber : Pengolahan data

Setelah order konsumen selesai dibuat pada proses produksi, owner akan menyuruh pegawai yang menganggur untuk mengangkut kaos ke gudang untuk disimpan dahulu sebelum pengiriman, yang kemudian akan dikirimkan ke konsumen baik melalui agen pengiriman atau oleh owner sendiri.

Owner sekarang tidak melakukan pencatatan dalam gudangnya untuk finished goods. Namun pencatatan di butuhkan untuk mengecek kembali apakah jumlah barang yang diproduksi sesuai dengan order yang diterima, jadi saat pengiriman tidak akan ada yang terlewat dengan adanya database warehouse untuk finished good ini. Dengan begitu, diusulkan pula database untuk warehouse finished good yang mencatat kaos yang telah jadi dan akan dikirimkan kepada konsumen, yaitu:

\section{Tabel 4}

\section{Tampilan Usulan Sistem Finished Goods} Inventory List

$\begin{array}{ll}\text { Total Inventory Value } & : 515 \\ \text { Client } & : \text { Corry } \\ \text { Inventory Items } & : 515\end{array}$

\begin{tabular}{|c|l|l|l|l|l|}
\hline $\begin{array}{c}\text { Jenis } \\
\text { Ka0s }\end{array}$ & $\begin{array}{c}\text { Warua } \\
\text { Ka0s }\end{array}$ & $\begin{array}{c}\text { Tanggal } \\
\text { Masulk }\end{array}$ & $\begin{array}{c}\text { Jumlah } \\
\text { Ka0s } \\
\text { Masulk }\end{array}$ & $\begin{array}{c}\text { Tanggal } \\
\text { Keluar }\end{array}$ & $\begin{array}{c}\text { Jumlah } \\
\text { Ka0s } \\
\text { Keluar }\end{array}$ \\
\hline Cowrok & Putih & $\begin{array}{l}15-12- \\
14\end{array}$ & 165 & $16-12-14$ & 165 \\
\hline Cewrek & & & 203 & & 203 \\
\hline Anak & & & 150 & & 150 \\
\hline Total & & & 518 & & 518 \\
\hline
\end{tabular}




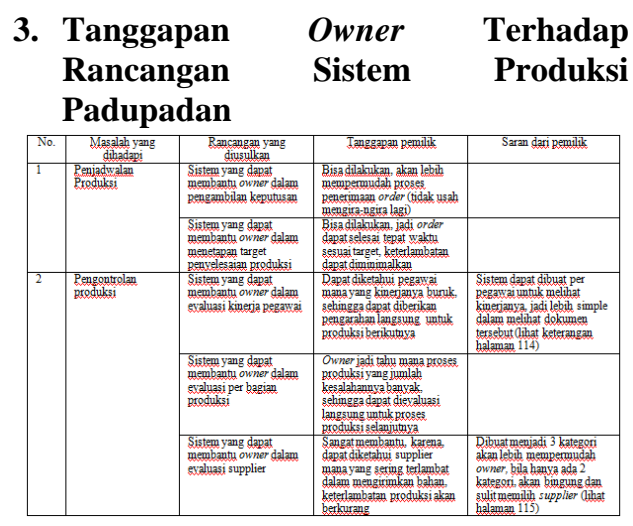

Maka, atas saran dari pemilik atas usulan yang dibuat, dicoba untuk dibuatkan tampilan sistem yang baru dan akan diperlihatkan pada tabel di bawah ini.

a. Sistem yang dapat membantu owner dalam evaluasi kinerja pegawai, yang dapat memperlihatkan penilaian kinerja pegawai perusahaan Padupadan per orang

Tabel 5

Tampilan Saran Pemilik, Sistem Kinerja Pegawai Perusahaan Padupadan (Per Pegawai)

Nama Pegawai : Dian

\begin{tabular}{|l|l|l|l|l|}
\hline No. & $\begin{array}{c}\text { Waltu } \\
\text { Produlsi }\end{array}$ & $\begin{array}{c}\text { Jumlah yang } \\
\text { Diprodulsi }\end{array}$ & $\begin{array}{c}\text { Hasil produlsi } \\
\text { tidal baik }\end{array}$ & $\begin{array}{c}\text { Kategori } \\
\text { Pegawai }\end{array}$ \\
\hline 1 & $\begin{array}{c}16-11-14- \\
25-11-14\end{array}$ & 108 & 4 & Cukup \\
\hline 2 & $\begin{array}{c}19-11-14- \\
27-11-14\end{array}$ & 112 & 2 & Baik \\
\hline 3 & $\begin{array}{l}4-12-14- \\
14-12-14\end{array}$ & 107 & 1 & Baik \\
\hline 4 & & & & \\
\hline
\end{tabular}

Kategori:

- Kesalahan produksi <3 termasuk ke dalam kategori pegawai yang baik dalam bekerja

- Kesalahan produksi antara 4 - 6 termasuk ke dalam kategori pegawai yang cukup dalam bekerja

- Kesalahan produksi antara >6 termasuk ke dalam kategori pegawai yang kurang baik dalam bekerja

Kategori yang dimaksud disini akan dirata-ratakan dari setiap kali produksi, lalu akan dibuat evaluasi dari kinerja masing-masing karyawan seluruhnya.
Dari kategori tersebut dapat diketahui dan juga dapat dibandingkan mengenai bagaimana kinerja pegawai tersebut dari waktu ke waktu, apakah meningkat, menurun ataukah tidak menentu.

b. Sistem yang dapat membantu owner dalam evaluasi supplier, yang atas saran dari owner meminta untuk dibuat menjadi 3 kategori akan lebih mempermudah owner, bila hanya ada 2 kategori, akan bingung dan sulit memilih supplier, karena jumlah supplier yang terbatas.

Tabel 6

Tampilan Saran Pemilik, Evaluasi Supplier Bahan

Supplier: XXX

\begin{tabular}{|l|l|l|l|}
\hline No. & Jenis Bahan & \multicolumn{1}{|c|}{$\begin{array}{c}\text { Keterlambatan supplier } \\
\text { (hari) }\end{array}$} & \multicolumn{1}{|c|}{$\begin{array}{c}\text { Kategori } \\
\text { Supplier }\end{array}$} \\
\hline 1 & $\begin{array}{l}\text { Kain kormbed } \\
20 \text { 's }\end{array}$ & 3 & B \\
\hline 2 & Kain katun xx & 4 & B \\
\hline 3 & Kain spandex & 5 & B \\
\hline
\end{tabular}

Kategori :

- A: Keterlambatan < 2hari, owner tidak harus berhati-hati dalam memesan barang kepada supplier

- B: Keterlambatan antara 3 - 5hari, owner harus berhati-hati dalam memesan barang kepada supplier

- C: Keterlambatan > 6hari, owner harus sangat berhati-hati dalam memesan barang kepada supplier karena jumlah hari keterlambatannya sangat lama Kesimpulan: terhadap supplier XXX, owner harus berhati-hati dalam memesan bahan, karena supplier suka terlambat dalam pengiriman bahannya sekitar 3 - 5 hari. 


\section{Simpulan dan Saran}

Berdasarkan hasil penelitian yang telah dilakukan pada Perusahaan Padupadan, dapat disimpulkan dan dapat memberikan saran dalam penerapan kontrol perusahaan, Production Control System berbasis computer untuk IKM garmen khususnya dalam masalah penjadwalan dan pengontrolan produksi.

\section{Simpulan}

Berdasarkan hasil penelitian dan pembahasan yang telah dilakukan sebelumnya, maka peneliti memiliki beberapa poin kesimpulan yang dapat menjawab pertanyaan penelitian, sebagai berikut:

1. Perusahaan ingin lebih meningkatkan kualitas pada produknya, namun untuk meningkatkan kualitas produk, Perusahaan harus memperbaiki mengenai masalah keterlambatan dan pengontrolan terhadap proses produksinya. Hal ini dapat dilihat pada MIT 90'S Framework (lihat bagan MIT 90'S framework dan keterangannya). Hal ini dilakukan dengan membuat target agar mencapai kualitas tersebut. maka, ada 9 (sembilan) kegiatan utama perusahaan yang akan dibahas berkaitan dengan permasalahan pada sistem Produksi perusahaan Padupadan. Kegiatan utama yang akan dibahas ini berhubungan dengan masalah yang akan dibahas, yaitu marketing akan menawarkan produknya kepada customer, setelah order diterima, akan dibuat sales order yang akan membantu dalam proses production schedulling. Disini, production schedulling akan mencatat bahan yang dibutuhkan untuk produksi yang kemudian akan diberikan kepada bagian purchasing dan receiving untuk membeli dan menerima bahan yang dipesan, lalu masuk ke bagian warehouse (raw materials) untuk menunggu bahan diproses ke dalam proses produksi. Selain itu production schedulling akan melihat jumlah pegawai yang dibutuhkan dalam proses produksi, bila kurang owner akan masuk ke bagian HRM. Sehingga bila bahan dan pegawai terpenuhi, proses produksi baru dapat terjadi. Setelah proses produksi selesai dikerjakan, sambil menunggu waktu pengiriman kepada customer, pesanan tersebut akan berlanjut ke bagian warehouse (finished goods).

2. Perusahaan Padupadan membutuhkan suatu sistem yang dapat suatu sistem yang dapat membantu owner dalam pengambilan keputusan yang berkaitan dengan order, karena itu diusulkan sistem yang dapat membantu owner untuk pengambilan keputusan untuk penerimaan order dan untuk menetapkan target pada penjadwalan produksi. Sistem untuk membantu dalam pengambilan keputusan dalam penerimaan order akan membantu owner dalam memutuskan apakah akan menerima order atau tidak dengan melihat production scheduling sebagai target, sedangkan penjadwalan produksi ini dibuat sebagai target pencapaian dari proses produksi dengan melihat sales order sebagai acuan, sehingga kemungkinan order menumpuk dan kemungkinan setiap proses mengalami keterlambatan sangat kecil karena sudah ditargetkan oleh owner sendiri, kapan proses produksi tiap bagian dimulai dan kapan selesai.

3. Untuk menghasilkan kualitas yang baik dalam pengerjaan produksi, owner dapat membuat dokumen pengontrolan produksi dan prosesnya, yang berisikan data mengenai berapa hari produksi telat dari yang dijadwalkan, mencatat jumlah dari produksi, mencatat berapa jumlah produksi yang baik dan kurang baik, juga mencatat berapa jumlah produksi yang dikerjakan karyawan tersebut. Dari data tersebut akan dievaluasi, sehingga dari laporan tersebut dapat dilihat dimana atau pada bagian yang mana proses produksi 
perlu ditingkatkan, apakah pengaruh dari faktor tenaga kerja ataukah pada proses produksinya sendiri (misal pada mesinnya). Sehingga dari evaluasi tersebut owner dapat mengambil tindakan ke depan untuk memperbaikinya.

Dari dokumen pengontrolan produksi diatas, akan didapatkan evaluasi pada Perusahaan Padupadan dalam 3 (tiga) jenis, yaitu:

- Untuk melihat kinerja pegawai Perusahaan Padupadan per bagian produksi, yang nantinya akan dapat dibandingkan setiap pegawainya.

- Proses Produksi akan di-group, nantinya akan dapat diketahui proses bagian apa yang menghasilkan banyak kesalahan atau hasil produksi yang tidak baik.

- Untuk mengkategorikan supplier bahan berdasarkan keterlambatan bahan yang dipesan.

4. Tanggapan owner mengenai sistem yang diusulkan, dalam hal penjadwalan sangat baik karena hal itu dapat memberikan target penyelesaian setiap prosesnya, sehingga keterlambatan produksi dapat berkurang. Kedepannya Perusahaan Padupadanpun akan dapat dikelola dengan baik dengan adanya sistem ini.

5. Sistem yang diusulkan ini merupakan sistem yang dapat membantu Perusahaan Padupadan dalam:

- Melakukan penjadwalan produksi dalam pengambilan keputusan yang berkaitan dengan order, yaitu untuk menerima order dan menetapkan target pengerjaan proses produksi.

- Melakukan pengontrolan produksi, khususnya dengan para pihak yang berkaitan dengan keberlangsungan proses produksi:

- Kinerja pegawai Perusahaan Padupadan (dapat diukur dan ditetapkan pegawai tersebut termasuk ke dalam kategori yang mana? Apakah baik / tidak baik ataukah cepat / sedang / lambat?
- Proses produksi mana yang menghasilkan banyak kesalahan, sehingga dari proses produksi tersebut dapat lebih diawasi lagi atau diberikan pengarahan ulang agar kesalahan yang terjadi pada proses produksi tersebut dapat berkurang.

- Mengkategorikan supplier bahan, sehingga owner dapat berhati-hati dalam memesan bahannya kepada supplier yang suka terlambat, dan dapat memperkirakan kapan bahan yang dipesan datang, sehingga proses produksi berlangsung tepat waktu.

\section{Saran}

Berdasarkan pembahasan dan kesimpulan yang telah ada, peneliti memiliki beberapa poin saran berkaitan dengan Production Control System yang mungkin dapat berguna dan bisa diterapkan pada Perusahaan Padupadan di kemudian hari, yaitu sebagai berikut:

1. Sebelum sistem tersebut diterapkan dalam Perusahaan Padupadan, perlu adanya penginputan data ke dalam sistem tersebut. Maka, sebaiknya perusahaan menyimpan data-data produksi dan data persediaannya. Hal ini dilakukan agar perusahaan mempunyai data-data yang lengkap untuk kemudian dimasukkan ke dalam sistem, sehingga sistem dapat bekerja dengan baik. Data tersebut dijadikan acuan untuk pengembangan perusahaan kedepannya, dari data yang didapat dan disimpan owner jadi mengetahui bagaimana design-design kaos yang pernah dibuatnya, sehingga dapat dilakukan pengembangan lagi ke depannya dalam hal konsep design menjadi lebih baik lagi.

2. Agar perusahaan lebih maju, owner harus mengubah sikapnya dari owner yang tidak terlalu peduli dalam proses produksi (sering ditinggal dan tidak diawasi) dan terlalu baik kepada 
pegawainya menjadi lebih tegas kepada pegawainya agar mereka lebih serius dalam mengerjakan pekerjaannya. Owner harus menegur pegawai yang tidak bekerja dengan serius dan diberi peringatan agar pegawai tersebut menjadi lebih baik lagi. Dari sistem yang dibuat, bila pegawai dirasa kurang baik owner harus dengan serius menegur, memarahi dan mencoba memberikan arahan atau pelatihan lagi untuk pegawai tersebut. Atau bisa dengan pemberian reward dengan syarat tertentu untuk memacu kinerja para pegawai. Sehingga kinerja pegawai semakin baik dari waktu ke waktu.

\section{Daftar Pustaka}

Ahira, A. (2005). Retrieved Febuari 2018, from

http://www.anneahira.com/pengertia n-garment.htm

Assauri, P. D. (2016). Manajemen Produksi dan Operasi. Jakarta: Lembaga Penerbit Fakultas Ekonomi UI.

C. Laundon, K., \& P. Laoudon, J. (2014). Decision Support System for Business Intelligence. New Jersey: Pearson Prentice Hall.

Caksamsul. (2013, September 13). Retrieved September 9, 2018, from http://ukm-indonesia.net/: http://ukm-indonesia.net/umkmmemiliki-peran-strategis.html

Charles T. Horngren, S. M. (2012). Cost Accunting (A Managerial Emphasis). New Jersey: Prentice Hall.

Charles T. Horngren, S. M., \& Madhav Rajan, C. I. (2017). Cost Accounting (A Managerial Emphasis). New Jersey: Prentice Hall.

Fiskal, B. K. (2014). Retrieved september 19, 2018, from http://www.tarif.depkeu.go.id: http://www.tarif.depkeu.go.id/Others $/$ ?hi=AFTA godam64. (2006, Mei 31). Retrieved September 9, 2018, from http://www.organisasi.org/: http://www.organisasi.org/1970/01/p engertian-definisi-macam-jenis-danpenggolongan-industri-di-indonesiaperekonomian-bisnis.html

Hanlim, P. (2014, Juni 12). Retrieved November 21, 2018, from http://hanlin88.blogspot.com: http://hanlin88.blogspot.com/2014/06/cuttingmachine-atau-mesin-potongkain.html

Hendra Teguh SE, A. (1996). Sistem Informasi Manajemen. PT Bhuana Ilmu Populer.

Hosey, S. (2013, April 2). Retrieved September 8, 2018, from http://soniahosey05.blogspot.com/: http://soniahosey05.blogspot.com/20 13/04/ukm-menjadi-penggerakpertumbuhan.html

Indonesia, K. P. R. (2012). Retrieved Febuari 2018, from inatrims.kemendag.go.id: http://inatrims.kemendag.go.id/id/pr oduct/detail/tekstil-dan-produktekstil 5

Levy,Margi P. P. (2005). Strategies for Growth in SMEs. United Kingdom: Elsevier .

Marakas, G. M. (2011). System Analysis and Design. New York: Pearson Education.

Marpaung, N. N. (2012, Oktober 19). Retrieved September 8, 2018, from http://nettinataridamarpaung.blogspo t.com/:

http://nettinataridamarpaung.blogspo t.com/2012/10/peran-ukm-dalamperekonomian-di.html

Mc.Leond, Raymond J. (2010). Studi Sistem Infrmasi Berbasis Komputer. Jakarta: PT. Prenhallindo.

McLeod, Raymond J. (2010). Sistem Informasi Manajemen. (A. Hendra Teguh, Trans.) Jakarta: PT Prenhallindo. 
Mutia, N. (2013, Desember). Retrieved September 9, 2018, from http://noormutia.blogspot.com/:

http://noormutia.blogspot.com/2013/ 12/analisis-pengaruh-aftaterhadap.html.

Neraca, H. E. (2011, November 21). Retrieved September 9, 2018, from http://www.neraca.co.id: http://www.neraca.co.id/industri/218 34/Bendung-Serbuan-ImporIndustri-Garmen-DimintaTingkatkan-Nilai-Tambah.

Oniel, E. (2012, Mei 2). Retrieved September 8, 2018, from http://hendrausahakecil.blogspot.co $\mathrm{m} /$ : http://hendrausahakecil.blogspot.co $\mathrm{m} /$

Silalahi, (2012). Metode Penelitian Sosial. Bandung: Refika Aditama.

Sugiyono, P. D. (2013). Metode Penelitian Bisnis. Bandung: Alfabeta, CV.

Tnoton. (2012). Retrieved November 21, 2018, from perlutahu.org: http://perlutahu.org/berkenalandengan-mesin-jahit-juki/

Vollmann, T. E., Berry, W. L., Whybark, D. C., \& Jacobs, F. R. (2011). Manufacturing Planning and Control for Supply chain Managemen. McGraw-Hill. 